\title{
Top management remuneration in a post-transition economy: does company ownership make a difference?
}

\author{
Ivana Načinović Braje \\ Faculty of Economics and Business, University of Zagreb, Zagreb, Croatia \\ Lovorka Galetić \\ Faculty of Economics and Business, University of Zagreb, Zagreb, Croatia
}

\begin{abstract}
Executive remuneration is considered among most important mechanisms to align interests of managers and company owners. This paper examines the role of company ownership as a determinant of top management compensation. The aim of the research was to determine the impact of ownership origin, domestic or foreign, on top management remuneration practices in a post-transition economy country. The research is based on a survey of top management remuneration practices among 60 medium and large sized Croatian companies. Research results indicate that foreign owned companies provide more annual bonuses, long-term compensation and additional benefits to higher percentages of top managers than domestically owned companies. Companies with domestic owners provide annual bonuses at higher ratios of base pay compared to foreign owned companies and position managerial pay at higher levels relative to comparative firms in the sector with foreign owners. Top managers, investors and firm owners should be aware that in post-transition economies compensation practices greatly differ between domestic and foreign owned companies.
\end{abstract}

\section{Keywords}

company ownership, post-transition, top management compensation

\section{Introduction}

The separation of ownership and control in contemporary organizations creates a context where top managers coordinate and control company's activities. However, in case they pursue specific behaviour that brings damage to the owners' interests they will not bear any personal financial loss except possible job loss and lost pay. This problem of managerial power and discretion, also known as the agency problem, creates prerequisites for potentially conflicting interests of top managers and owners (Pepper \& Gore, 2015). Due to the fact that managerial actions cannot be perfectly observed by shareholders, agency theory predicts that under such circumstances compensation policy for top management must provide incentives to select and implement actions that increase shareholder wealth (Pereira \& Esperança, 2015).
The amount of top management compensation rose dramatically during the 1980s and 1990s, which initiated much debate on the determinants and consequences of managerial pay (Frydman \& Saks, 2010). Due to these extremely high levels of compensation, the topic of executive remuneration had a strong proliferation both with the popular press and the academic literature, with many critics claiming that amounts paid to executives are excessive (e.g. Kaplan, 2008). Abundant top management compensation academic literature covers numerous theoretical and practical issues within top management compensation. However, most of these contributions are based on data from Anglo-Saxon countries with Anglo-American system of corporate governance. Still, the issue of top management compensation is very country specific and dependent upon the country-specific regulation and level of separation of ownership 
and control (Rampling, Eddie \& Liu, 2013, Pereira \& Esperança, 2015).

Very little is known about top management compensation among countries employing continental system of corporate governance, especially among European post-transition economies, although there has been growing interest to understand these practices (e.g. Berber, Morley, Slavić \& Poór, 2017). Central and Eastern European (CEE) economies have undergone transition processes which have established new ownership structure, a change in managers' profile and change in the reward system. The controlled wages of the centrally planned systems were liberalized, which resulted in stronger wage differences between employees (Festing \& Sahakiants, 2013). With respect to top managers, a key feature of the new reward system was abandoning egalitarian compensation practices and introducing higher levels of compensation for top managers relative to other wage earners (Eriksson, 2005, p. 660).

Existing studies on general trends in compensation management in transition economies emphasize some differences in compensation practices with respect to ownership structure with foreign owned companies offering higher levels of compensation (e.g. Eriksson, 2005). Studies on compensation management in Croatia support this finding. Out of the 20 companies with highest salaries in Croatia in 2017, 16 are owned by foreign owners (FINA, 2018). Based on these findings, the focus of this research was to answer the following research questions: RQ1: What are the most important determinants of top management compensation in post-transition economies? RQ2: What is the structure of top management compensation in post-transition economies? RQ3 Are there any differences in the determinants and structure of top management compensation between companies with domestic and/or foreign owners.

The purpose of this paper is to provide new insight into the practices of top management compensation in post-transition economies. For this purpose, two hypotheses were set:

H1: Determinants of top management remuneration in Croatian companies in domestic and foreign ownership differ greatly.

H2: Foreign owned companies use variable compensation more often than domestic owned companies.

The paper first presents a theoretical background on the structure and determinants of top management compensation. This is followed by a description of methodology, an analysis of current practices of top management compensation among domestic and foreign owned companies and discussion and conclusion of findings.

\section{Theoretical background}

\subsection{Structure of top management remuneration}

Top management compensation packages include several components, where each of these components has differing effects on employee motivation as well as different costs for the organization (Agarwal, 2010). Most common components of compensation are salary, bonus, long term incentives such as stock options and stock grants, pensions, benefits and perks. Among these, base pay will have the greatest impact on attracting and retaining top managers, while shortterm incentives will be important for top management's motivation and as a form of recognition. Long-term incentives will have an impact on retaining top managers. Benefits are the most important as the form of recognition (Ellig, 2007). A well-designed compensation plan must make trade-offs between the components to maximize the net benefit to both the corporation and the top management.

In publicly traded companies, top management compensation package is determined by the compensation committee. The committee's task is to propose the content of executive directors' compensation package, which is then to be confirmed by the full board. Research has found that the overall compensation package can depend upon the number of factors related to the committee and the corporate governance such as size and composition of the compensation committee (board of directors), board member independence, types of shareholders, ownership structure or executive directors' share ownership (e.g. Vafeas, 2003; Gregory-Smith, 2012).

The processes of structuring top management compensation packages in transition economies does not necessarily follow all theoretical expectations established within Anglo-American system of corporate governance, especially with respect to equity-based compensation in the form of stock options that has caused rapid growth of the overall amounts received by top executives in such countries (Farid, Conte \& Lazarus, 2011). Furthermore, Beer \& Katz (2003) found that the 
egalitarian social values of Europeans cause them to have negative views of executive incentive systems known in the USA.

\subsection{Determinants of top management remuneration}

Empirical research into the determinants of executive remuneration has accumulated many individual factors that can have an impact on executives' compensation packages. These include firm performance (Conyon \& Sadler, 2001; Combs \& Skill, 2003; McKnight \& Tomkins, 2004), company size (Singh \& Agarwal, 2003; Chalmers, Koh, \& Stapledon, 2006; Sakawa \& Watanabel, 2008), level of growth (Firth, Tam, \& Tang, 1999), job complexity (Santalo \& Knock, 2009), company complexity (diversification) (Matolcsy \& Wright, 2006) or strategy (Singh \& Agarwal, 2003). Some determinants are related to top management tenure or age (McKnight \& Tomkins, 2004), internal/external promotion to the position (Johnston, 2005), education (Pereira \& Esperança, 2015), work experience (Bragaw \& Misangyi, 2017) or gender (Kulich, Trojanowski, Ryan, Haslam, \& Renneboog, 2011).

Although academic literature recognizes an abundance of top management remuneration determinants, some of them have been more often emphasized. The size construct, either in terms of sales, assets, number of employees or market share, has been a unanimously confirmed predictor of compensation by many authors (e.g. Finkelstein \& Boyd, 1998; Rahman \& Mustafa, 2018). Tosi, Werner, Katz \& Gomez-Mejia (2000) show that firm size accounts for more than $40 \%$ of the variance in total CEO pay, while firm performance accounts for less than $5 \%$ of the variance.

Firm performance is also an important determinant of top management compensation, directly following from the agency theory perspective. It is probably the most researched determinant of top management remuneration with still lacking finite conclusions. Research on different data sets and different measures of performance (e.g. aggregate/relative financial performance, non-financial performance etc., see Perry \& Zenner, 2001; Epstein \& Roy, 2005, Rahman \& Mustafa, 2018) produced sometimes contradictory conclusions.

Ownership structure has been an oftenresearched determinant of top management remuneration as well (e.g. Sakawa \& Watanabel, 2008). However, the focus of such research was on the dispersion of ownership (Jones \& Mygind, 2011), institutional ownership (Victoravich, Xu \& Gan, 2012), family ownership (Cheng, Lin \& Wei, 2015) or employee ownership (Jones \& Mygind, 2011) and its impact on aspects of remuneration. Research on the impact of the foreign ownership on executive remuneration is very scarce. To the best of the authors' knowledge, only a few studies analyse the effects of ownership origin (private/foreign) on the compensation system (Aitken, Harrison \& Lipsey, 1996; Almeida, 2007; Shinozaki, Moriyasu \& Uchida, 2016; Kang \& Nanda, 2017). These studies all tend to find a wage premium in foreign owned firms. Except for higher total remuneration among foreign owned firms, some authors study the relationship between foreign ownership and the structure of compensation package (e.g. Cho, Huang \& Padmanabhan (2014) did not found a relationship between ownership structure and long term executive compensation; Yoshikawa, Rasheed \& Del Brio (2010) found that foreign owned firms reduce cash bonus payments, but are more likely to use equity compensation in the form of stock options (Shinozaki et al., 2016)).

\subsection{The role and growth of foreign ownership in transition economies}

A common characteristic of all post-transition countries is a shift from social to private ownership. Privatization, accompanied with the inflow of foreign direct investment, resulted with a number of companies with a proportion of shares owned by foreign entities (Apostolov, 2013) and modern working arrangements (Chessell, 2018; Nica, 2018). Following such ownership structure, companies can be categorized based on their dominant owners as domestic or foreign owned. Foreign ownership is expected to have a positive impact on firm performance (Desender, Aguilera, Lópezpuertas-Lamy \& Crespi, 2016; Ciftci, Tatoglu, Wood, Demirbag \& Zaim, 2019) due to both resources and knowledge transfer. In the context of the finding that companies from Central and Eastern Europe (CEE) lag behind their western counterparts (World Economic Forum, 2014), it is interesting to explore the level of implementation of western practices within top management remuneration and the differences between domestic and foreign owned companies with respect to top management remuneration in posttransition CEE countries. 


\section{Methodology}

\subsection{Sample and data}

The population for the primary research were large and medium-sized Croatian companies since those are expected to have more sophisticated HRM practices in general and reward practices in specific. The population of Croatian companies that employ more than 100 employees was obtained through Croatian Chamber of Commerce (CCC), where it was revealed that approximately 1700 companies in Croatia (excluding banking and finance sector) employ more than 100 people, out of which 386 companies employ more than 250 people (labelled as "large companies"). This research is based on a sample of 60 companies.

With respect to ownership structure, the sample consisted of $56.7 \%$ of companies with majority private domestic ownership $(n=34)$, $33.3 \%$ of companies with majority private foreign ownership $(n=20)$ and $10 \%$ of companies with either state (public) ownership or mixed ownership. Since the objective of this research was to compare companies with private domestic and foreign ownership, companies with mixed ownership were omitted from further research, so that research sample included 54 remaining companies.

The independent characteristics of the companies in the sample are given in a summary table below (Table 1). The statistical analysis of the primary data was conducted by using IBM SPSS 21 software.

Table 1 Data distribution by sample characteristics

\begin{tabular}{|c|c|c|c|}
\hline $\begin{array}{l}\text { Company } \\
\text { characteristic }\end{array}$ & $\begin{array}{l}\text { Total sample } \\
(n=60)\end{array}$ & $\begin{array}{l}\text { Private } \\
\text { domestic } \\
\text { companies } \\
(n=34) \\
\end{array}$ & $\begin{array}{l}\text { Private foreign- } \\
\text { owned } \\
\text { companies } \\
(n=20)\end{array}$ \\
\hline Industry & $\begin{array}{l}\text { Manufacturing - } \\
52.54 \% \\
\text { Services - } \\
47.46 \%\end{array}$ & $\begin{array}{l}\text { Manufacturing - } \\
52.9 \% \\
\text { Services - } \\
47.1 \% \\
\end{array}$ & $\begin{array}{l}\text { Manufacturing - } \\
42.86 \% \\
\text { Services - } \\
57.14 \%\end{array}$ \\
\hline $\begin{array}{l}\text { Year of } \\
\text { establishment }\end{array}$ & \begin{tabular}{|l} 
Before 1990 - \\
$46.70 \%$ \\
After 1990 - \\
$53.30 \%$
\end{tabular} & $\begin{array}{l}\text { Before } 1990 \text { - } \\
44.1 \% \\
\text { After } 1990 \text { - } \\
55.9 \%\end{array}$ & \begin{tabular}{|l} 
Before 1990 - \\
$35.00 \%$ \\
After 1990 - \\
$65.00 \%$
\end{tabular} \\
\hline $\begin{array}{l}\text { Number of } \\
\text { employees }\end{array}$ & $\begin{array}{l}\text { Less than } 250- \\
51.70 \% \\
\text { More than } 250 \text { - } \\
48.30 \%\end{array}$ & $\begin{array}{l}\text { Less than } 250- \\
50.00 \% \\
\text { More than } 250- \\
50.00 \%\end{array}$ & $\begin{array}{l}\text { Less than } 250- \\
65.00 \% \\
\text { More than } 250 \text { - } \\
35.00 \%\end{array}$ \\
\hline
\end{tabular}

\begin{tabular}{l|l|l|l}
\hline Legal form & Joint stock & Joint stock & Joint stock \\
& company - & company - & company - \\
& $33.30 \%$ & $29.40 \%$ & $30.00 \%$ \\
& Limited liability & Limited liability & Limited liability \\
& company - & company - & company - \\
& $66.70 \%$ & $70.60 \%$ & $70.00 \%$ \\
\hline Profitability in the & Cannot assess - & Cannot assess - & Cannot assess - \\
last 5 years & $1.70 \%$ & $0 \%$ & $5.00 \%$ \\
& Unprofitable - & Unprofitable - & Unprofitable - \\
& $5.00 \%$ & $5.90 \%$ & $5.00 \%$ \\
& Around or below & Around or below & Around or below \\
& average - & average - & average - \\
& $23.30 \%$ & $20.60 \%$ & $20.00 \%$ \\
& Profitable - & Profitable - & Profitable - \\
& $70.00 \%$ & $73.50 \%$ & $70.00 \%$ \\
\hline
\end{tabular}

Source: Authors' work

As shown in Table 1, research sample included companies with long tradition established before $1990(46.7 \%)$ and those established during or after the transition period that started in 1990 (53.3\%). Among foreign owned companies, the sample included more companies that were established during 1990 or later $(65.0 \%)$. The sample had similar proportion of companies with fewer than 250 employees (51.7\%) and more than 250 employees $(48.3 \%)$. Among foreign owned companies, most of them employed fewer than 250 employees (65\%). This research covered both joint stock companies (33.3\%) and limited liability companies (66.7\%). According to the companies' self-reported profitability in the last 5 years, $70 \%$ of companies were profitable, $23.3 \%$ were of average or below average profitability and $5 \%$ were unprofitable.

\subsection{Research instrument}

A questionnaire containing 46 questions was designed by the authors for the purpose of primary data collection. This research is part of a larger project aimed at exploring reward practices is Croatia. Majority of key questions about different reward management strategies were found or adapted in different journal articles as well as Chartered Institute for Personnel Development internal materials. An e-mail with cover letter and link to the questionnaire was sent to managers of HR departments of all companies in the CCC database in April 2017. Reminders were sent out in May and June, followed by personal reminders to HR managers of different project members using professional networks. The allotted time for completing the questionnaire was approximately 30 to 45 minutes. The respondents, HR managers, were asked to provide information on whether each examined pay practice existed in their organization and its features. Most variables 
of interest were assessed on a Likert type scale, e.g. the importance of several determinants of top management remuneration was assessed on a 5point Likert-type scale $(1=$ no impact, $5=$ dominant impact). Some variables were of nominal character and control variables were designed almost exclusively as closed-ended questions, such as ownership type, profitability in the last five years and legal form of the company. Several open-ended questions were present as well (e.g. year of establishment, industry, number of employees).

\subsection{Statistical analysis}

Arithmetic means were used to describe the impact of several compensation determinants. The non-parametric Mann-Whitney U test was used to compare two independent groups (foreign owned and domestic owned companies) for the importance of compensation determinants. Fisher's exact test was used to test the difference between foreign owned and domestic owned companies for distribution of compensation components and ratio of yearly bonus to annual pay due to categorical data.

\section{Results}

According data from Table 2, the most important determinant of top management compensation is managers' personal characteristics. It is even more important for companies in domestic ownership $(\bar{x}=4.3$, s.d. $=.68)$ than for those in foreign ownership $(\overline{\mathrm{x}}=4.05$, s.d. $=.89)$. Except for personal characteristics, domestic owned companies rated skills important for the position $(\overline{\mathrm{x}}=3.85$, s.d. $=.82)$ and economic situation in the industry $(\overline{\mathrm{x}}=3.41$, s.d.=.86) as relatively important determinants. Foreign owned companies reported that, besides personal characteristics, they also find skills important for the position as an important determinant of top management compensation $(\overline{\mathrm{x}}=3.45$, s.d. $=1.1)$, equally important as company size and complexity $(\bar{x}=3.45$, s.d. $=1.0)$. MannWhitney $U$ test showed statistically significant difference between foreign and domestic owned companies only for the determinant position attractiveness $($ at $\mathrm{p}<0.1)$. This determinant was more important for foreign owned companies.
Table 2 Determinants of top management remuneration in a post-transition country

\begin{tabular}{l|l|l}
\hline & $\begin{array}{l}\text { Private domestic } \\
\text { ownership N=34 } \\
\text { Mean } \\
\text { (Standard } \\
\text { deviation) }\end{array}$ & $\begin{array}{l}\text { Private foreign } \\
\text { ownership N=20 } \\
\text { Mean } \\
\text { (Standard } \\
\text { deviation) }\end{array}$ \\
\hline $\begin{array}{l}\text { Benchmark at the } \\
\text { industry level }\end{array}$ & $\begin{array}{l}2.529 \\
(1.2119)\end{array}$ & $\begin{array}{l}2.900 \\
(1.1192)\end{array}$ \\
\hline $\begin{array}{l}\text { Company size and } \\
\text { complexity }\end{array}$ & 3.088 & 3.450 \\
& $(0.9331)$ & $(0.9987)$ \\
\hline $\begin{array}{l}\text { Market position and } \\
\text { status }\end{array}$ & 3.029 & 3.200 \\
$(0.9996)$ & $(1.0563)$ \\
\hline $\begin{array}{l}\text { Position } \\
\text { attractiveness }\end{array}$ & 2.500 & 3.100 \\
\hline $\begin{array}{l}\text { General economic } \\
\text { situation }\end{array}$ & 2.882 & $(1.1653)$ \\
\hline $\begin{array}{l}\text { Skills important for } \\
\text { the specified }\end{array}$ & $(1.0080)$ & 3.000 \\
position & $(0.8214)$ & $(1.1698)$ \\
\hline $\begin{array}{l}\text { Personal } \\
\text { characteristics (e.g. } \\
\text { qualifications, work } \\
\text { experience, work } \\
\text { outcomes) }\end{array}$ & $(0.6840)$ & $(1.0990)$ \\
\hline $\begin{array}{l}\text { Current economic } \\
\text { situation in the } \\
\text { industry }\end{array}$ & 3.412 & 4.050 \\
\hline & $(0.8570)$ & $(0.8870)$ \\
& & \\
\hline
\end{tabular}

Source: Authors' work

The occurrence of different forms of compensation for top managers is shown in Table 2. An earlier research into top management remuneration in Croatia by Načinović (2012) revealed that almost $1 / 4(23.68 \%)$ of companies do not use any form of variable compensation. On average, compensation package included $82.92 \%$ of fixed pay and $17.08 \%$ of variable pay. Furthermore, the same research showed that, although a very popular form of compensation among the developed countries, equity compensation lags in popularity in transition economies (offered by only $18.42 \%$ of sampled companies).

This research found several differences comparing domestic and foreign owned companies: (1) annual bonus is more often used by foreign companies (a high proportion of $29.4 \%$ of domestic companies still do not offer it to its top managers, whereas $80 \%$ of foreign firms provide it to most or all top managers); (2) long term bonus is very rarely offered to top managers, it is slightly more often found in foreign owned companies but rates of use are very low; (3) equity based compensation is just sporadically used by companies in this post-transition 
economy country; (4) benefits are more often used by foreign owned companies, since a high proportion of $44.1 \%$ domestic owned companies do not offer additional perks to top managers.

Results presented in Table 3 suggest that top management remuneration practices in (post)transition economy countries differ from those adopted by companies in Anglo-Saxon countries. Although this was expected considering different corporate governance systems and ownership structures, research results indicate absence of any convergence of practices in a posttransition economy and practices in developed countries. As the basic form of variable remuneration for managers, annual bonus is for more than half of sampled domestic-owned companies either non-existent or offered to just 1$20 \%$ of top managers (very likely just the CEO). More sophisticated reward practices (e.g. equitybased compensation) are almost non-existent among Croatian companies although, as explained in study limitations, this might be the consequence of sampled companies' profile. However, a general conclusion that can be drawn from table 3 is that foreign owned companies have slightly more developed top management compensation practices since they offer all examined forms of compensation to a higher percentage of top managers.

Table 3 Distribution of compensation components among private and foreign owned companies

\begin{tabular}{|c|c|c|c|c|c|c|}
\hline \multirow{2}{*}{ Component } & & \multirow{2}{*}{\multicolumn{5}{|c|}{$\%$ of companies }} \\
\hline & & & & & & \\
\hline \multirow{3}{*}{ Annual bonus } & & & & & & \\
\hline & Domestic & 29.4 & 32.4 & 2.9. & 2.9 & 32.4 \\
\hline & Foreign & 10.0 & 10.0 & 0 & 0 & 80.0 \\
\hline \multirow[t]{2}{*}{ Long term bonus } & Domestic & 91.2 & 5.9 & 0 & 0 & 2.9 \\
\hline & Foreign & 75.0 & 5.0 & 10.0 & 0 & 10.0 \\
\hline \multirow{2}{*}{$\begin{array}{l}\text { Shares, options and other forms of } \\
\text { equity }\end{array}$} & Domestic & 85.3 & 5.9 & 0 & 0 & 8.8. \\
\hline & Foreign & 75.0 & 10.0 & 5.0 & 0 & 10.0 \\
\hline \multirow[t]{2}{*}{ Additional benefits } & Domestic & 44.1 & 17.6 & 11.8 & 5.9 & 20.6 \\
\hline & Foreign & 10.0 & 25.0 & 0 & 5.0 & 60.0 \\
\hline
\end{tabular}

Source: Authors' work

In the following step the ratio of top management annual bonus was compared to annual base pay. Table 2 showed that many companies in domestic ownership do not offer annual bonus to its employees, however, according to Table 4, it seems that companies in domestic ownership tend to use higher relative amounts of annual bonus. This finding was somewhat surprising, since it could be expected that foreign owners due to their inability for direct supervision use some form of pay for performance schemes. However, as shown in Table 3, foreign owned firms offer other forms of compensation (especially long-term incentives and benefits) and thus possibly offer lower relative amounts of annual bonuses. Also, it must be emphasized that ownership concentration might moderate the amount of annual bonus but it was not controlled as a part of this research.
Table 4 The approximate ratio of yearly bonus to annual base pay for companies offering annual bonus

\begin{tabular}{l|c|c}
\hline \multirow{2}{*}{$\begin{array}{l}\text { Yearly bonus to annual base } \\
\text { pay }\end{array}$} & \multicolumn{2}{|c}{ Majority ownership } \\
\cline { 2 - 3 } & Domestic & Foreign \\
\hline Up to $10 \%$ & $13.6 \%$ & $20.0 \%$ \\
\hline $10-20 \%$ & $18.2 \%$ & $30.0 \%$ \\
\hline $20-50 \%$ & $18.2 \%$ & $30.0 \%$ \\
\hline $50-100 \%$ & $22.7 \%$ & $10.0 \%$ \\
\hline $\begin{array}{l}\text { Double or more than double } \\
\text { salary }\end{array}$ & $27.3 \%$ & $10.0 \%$ \\
\hline
\end{tabular}

Source: Authors' work

Since research data confirms that foreign owned firms offer higher salaries than companies with majority domestic ownership, companies' intended positioning of managerial compensation relative to comparative firms in the sector was examined next. 
Ivana Načinović Braje et al. Top management remuneration in a post-transition economy: does company ownership make a difference?

Table 5 Positioning of managerial compensation relative to comparative firms in the sector

\begin{tabular}{l|c|c}
\hline Positioning of managerial & \multicolumn{2}{|c}{ Majority ownership } \\
\cline { 2 - 3 } compensation & Domestic & Foreign \\
\hline $\begin{array}{l}\text { Within the bottom 10\% (10th } \\
\text { percentile) of sectoral comparators }\end{array}$ & $2.9 \%$ & $0 \%$ \\
\hline $\begin{array}{l}\text { Within the lower quartile (25th } \\
\text { percentile) of sectoral comparators }\end{array}$ & $0 \%$ & $5.0 \%$ \\
\hline $\begin{array}{l}\text { At or close to the relevant market } \\
\text { median (e.g. mid-point of sectoral } \\
\text { range for group) }\end{array}$ & $38.2 \%$ & $65.0 \%$ \\
\hline $\begin{array}{l}\text { Within the upper quartile (75th } \\
\text { percentile) of sectoral comparators }\end{array}$ & $20.6 \%$ & $10.0 \%$ \\
\hline $\begin{array}{l}\text { Within the top 10\% (90th } \\
\text { percentile) of sectoral comparators }\end{array}$ & $26.5 \%$ & $20.0 \%$ \\
\hline $\begin{array}{l}\text { Don't know/do not collect this } \\
\text { information }\end{array}$ & $11.8 \%$ & $0 \%$ \\
\hline Total & $100 \%$ & $100 \%$ \\
\hline
\end{tabular}

Source: Authors' work

Table 5 indicates that majority of foreign owned companies $(65 \%)$ aim at paying their top managers around relevant market median. Among domestic companies many of them aim at paying top managers above average amounts. Such finding might result from the fact that foreign owned firms have a more systematic approach to top management remuneration and use salary surveys and benchmark information when determining compensation packages. Additional reason for this might be that foreign owned firms have an image of more attractive employer thus domestic companies must increase offered compensation amounts to attract top-talent top managers. Also, foreign owned firms offer as a part of the compensation package long term incentives and benefits that are sometimes neglected by companies in domestic ownership.

Descriptive analyses showed some clear differences in top management remuneration practices between sampled foreign and domestic companies in Croatia. As a part of the research it was examined weather these can be generalized to the population of medium sized and large companies.

Table 6 List of statistically significant differences in compensation between majority foreign and domestic owned companies

\begin{tabular}{|c|c|c|c|}
\hline Feature & $\begin{array}{l}\text { Significant } \\
\text { differences }\end{array}$ & $\begin{array}{l}\text { Test } \\
\text { used }\end{array}$ & Implication \\
\hline \multirow[t]{2}{*}{$\begin{array}{l}\text { Distribution of } \\
\text { compensation } \\
\text { components }\end{array}$} & $\begin{array}{l}\text { Annual } \\
\text { bonus } \\
(p=0.009)\end{array}$ & \multirow[t]{2}{*}{$\begin{array}{l}\text { Fisher's } \\
\text { exact } \\
\text { test }\end{array}$} & \multirow{2}{*}{$\begin{array}{l}\text { Foreign owned } \\
\text { companies } \\
\text { provide these } \\
\text { forms of } \\
\text { compensation to a } \\
\text { higher percentage } \\
\text { of top managers. }\end{array}$} \\
\hline & $\begin{array}{l}\text { Benefits } \\
(p=0.007)\end{array}$ & & \\
\hline
\end{tabular}

\begin{tabular}{|c|c|c|c|}
\hline $\begin{array}{l}\text { The } \\
\text { approximate } \\
\text { ratio of yearly } \\
\text { bonus to annual } \\
\text { base pay for } \\
\text { companies } \\
\text { offering annual } \\
\text { bonus }\end{array}$ & $\begin{array}{l}\text { Statistically } \\
\text { significant } \\
\text { difference } \\
(p=0.030)\end{array}$ & $\begin{array}{l}\text { Fisher's } \\
\text { exact } \\
\text { test }\end{array}$ & $\begin{array}{l}\text { Private } \\
\text { companies with } \\
\text { domestic owners } \\
\text { tend to provide } \\
\text { annual bonuses } \\
\text { that are at higher } \\
\text { percentages of } \\
\text { base salary for } \\
\text { top managers }\end{array}$ \\
\hline $\begin{array}{l}\text { Positioning of } \\
\text { managerial } \\
\text { compensation } \\
\text { relative to } \\
\text { comparative } \\
\text { firms in the } \\
\text { sector }\end{array}$ & $\begin{array}{l}\text { Statistically } \\
\text { significant } \\
\text { difference } \\
(p=0.017)\end{array}$ & $\begin{array}{l}\text { Fisher's } \\
\text { exact } \\
\text { test }\end{array}$ & $\begin{array}{l}\text { When compared } \\
\text { with foreign } \\
\text { owned } \\
\text { companies, } \\
\text { private companies } \\
\text { with domestic } \\
\text { owners tend to } \\
\text { position } \\
\text { compensation } \\
\text { higher than } \\
\text { sectoral } \\
\text { comparators }\end{array}$ \\
\hline
\end{tabular}

After using Fisher's exact test some statistically significant differences were found in the distribution of compensation packages in foreign and domestic companies, precisely annual bonus $(p=0.009)$ and benefits $(p=0.007)$. The same test was used to test the difference in the ratio of yearly bonus to annual base pay between domestic and foreign owned companies and it showed a statistically significant difference $(p=0.030)$. Furthermore, Fisher's exact test confirmed statistically significant difference with positioning of managerial compensation relative to comparative firms in the sector $(p=0.017)$ among domestic and foreign owned companies.

\section{Discussion and conclusion}

Top management remuneration is an oftenresearched topic. However, possibilities for generalizing conclusions globally are somewhat limited. The practice of top management remuneration depends upon country-specific factors such as corporate governance system, ownership concentration, legal and tax system etc. Current knowledge on top management remuneration in European transition economies is highly limited. During the transition period many of these countries supported foreign investments which resulted in increased number of companies being owned by foreign investors. In most of these countries companies in majority foreign ownership are usually known for paying higher compensation levels compared to companies in domestic ownership. The purpose of this paper was to determine the patterns of top management remuneration in a post-transition economy, and 
specifically to compare practices in domestic and foreign owned companies. For this purpose, we used results of a primary research conducted in Croatia.

When making decisions about compensation, the first research question was to identify the important determinants of top management compensation in (post)transition economies. Among the determinants researched as a part of this study, the most important determinant of top management compensation for Croatian companies is managers' personal characteristics. Managers' personal characteristics such as age, education, work experience etc. have been an often-recognized determinant of top management remuneration (McKnight \& Tomkins, 2004; Pereira \& Esperança, 2015 etc.). Considering that top managers negotiate on their salaries and receive a unique compensation package, such finding does not come as a surprise. Research results indicate that besides formal qualifications, companies also emphasized the importance of skills necessary for the job position. On the other hand, benchmark at the industry level was rated as a determinant of minor importance. Other determinants which have been empirically proved to impact overall compensation such as company size and market position (performance) in the researched post-transition economy have only moderate importance for the overall compensation package.

When comparing determinants of top management compensation in companies with domestic and foreign ownership, it can be concluded that companies in domestic ownership give more attention to managers' attributes and skills than companies in foreign ownership. Companies in foreign ownership value company size and complexity, market position and economic situation in the company more than companies with domestic owners. Despite these differences in the importance of compensation determinants, additional testing did not provide many statistically significant differences among domestic and foreign owned companies. The only compensation determinant that has proven statistical difference between companies in domestic and foreign ownership is position attractiveness. This determinant is perceived by companies in domestic ownership as just moderately important, whereas companies in foreign ownership rated it as slightly more important. However, these results are statistically significant and therefore it can be generalized that in the population of Croatian companies those companies in foreign ownership acknowledge more position attractiveness as a determinant of top management remuneration $(p=0.061)$. All other determinants did not show any statistically significant difference with respect to ownership origin. These findings provide only partial support to $\mathrm{H} 1$.

The second research question was to identify the structure of top management compensation in (post)transition economies. The exploration of distribution of compensation components among top managers has revealed that foreign owned companies more often combine different forms of compensation. Similarly to research by Načinović (2012), it has been confirmed once again that there are still quite a few companies that do not use any form of variable compensation for their top managers. For example, for companies in domestic ownership, $29.4 \%$ do not provide annual bonuses, $91.2 \%$ do not provide long-term bonuses, $85.3 \%$ do not provide equity compensation and $44.1 \%$ of sampled companies do not provide additional benefits.

The final research question aimed at exploring differences in the determinants and structure of top management compensation between companies with majority domestic and/or foreign owners. Research findings suggest that there is still a large gap between top management remuneration in companies in post-transition economies and those in more developed countries. Although some of these differences can be the result of country-specific systems of corporate governance, research results indicate very low usage of variable compensation practices in companies with majority domestic ownership. Foreign owned companies provide other forms of compensation at slightly higher rates, but even these rates are much lower than among developed countries. The differences in the utilization of selected compensation components are statistically significant (annual bonus $\mathrm{p}=0.009$ and additional benefits $\mathrm{p}=0.007$ ). These results provide support for $\mathrm{H} 2$, since foreign owned firms use variable compensation more often than domestic owned firms.

There are some additional differences between domestic and foreign owned companies. For example, although foreign owned firms usually pay higher salaries, this research has shown that foreign owned firms initially aim at paying compensation at or close to the relative market median, whereas majority of domestic companies 
aim either at market median or above.

This research has confirmed that the origin of ownership, either domestic or foreign, is an influential determinant of the top management remuneration practices. There are several limitations to this study. Sampled firms were classified as foreign-owned if more than 50 percent of the firm's capital was in foreign hands. In case companies had a smaller foreign capital share they were included either in the category domestic ownership or mixed ownership although they might have transferred compensation practices from the foreign owner. This research included both joint stock companies and limited liability companies so some forms of compensation (e.g. equity remuneration) are more often applicable by public limited companies.

\section{Acknowledgement}

This research was funded by Croatian Science Foundation, project CompCroEU.sm

\section{References}

Agarwal, A. S. (2010), Motivation and Executive Compensation. IUP Journal of Corporate Governance, 9(1-2), 27-46.

Aitken, B., Harrison, A., \& Lipsey, R. E. (1996). Wages and foreign ownership A comparative study of Mexico, Venezuela, and the United States. Journal of International Economics, 40(3-4), 345-371. https://doi.org/10.1016/0022-1996(95)01410-1

Almeida, R. (2007). The labor market effects of foreign owned firms. Journal of International Economics, 72(1), 75-96.

https://doi.org/10.1016/j.jinteco.2006.10.001

Apostolov, M. (2013). Governance and enterprise restructuring in Southeast Europe. International Journal of Social Economics, 40(8), 680-691. https://doi.org/10.1108/IJSE-07-2012-0124

Beer, M., \& Katz, N. (2003). Do incentives work? The perceptions of a worldwide sample of senior executives. Human Resource Planning, 26(3), 30-44.

Berber, N., Morley, M. J., Slavić, A., \& Poór, J. (2017). Management compensation systems in Central and Eastern Europe: a comparative analysis. The International Journal of Human Resource Management, 28(12), 1661-1689. https://doi.org/10.1080/09585192.2016.1277364

Bragaw, N. A., Misangyi, V. F. (2017). The Value of CEO Mobility: Contextual Factors That Shape the Impact of Prior CEO Experience on Market Performance and CEO Compensation. Human Resource Management, 56 (2), 243-265. https://doi.org/10.1002/hrm.21737

Chalmers, K., Koh, P. S., \& Stapledon, G. (2006). The determinants of CEO compensation: Rent extraction or labour demand?. The british accounting review, 38(3), 259-275. https://doi.org/10.1016/j.bar.2006.01.003
Cheng, M., Lin, B., \& Wei, M. (2015). Executive compensation in family firms: The effect of multiple family members. Journal of Corporate Finance, 32, 238257. https://doi.org/10.1016/j.jcorpfin.2014.10.014

Chessell, D. (2018). The Jobless Economy in a Post-Work Society: How Automation Will Transform the Labor Market. Psychosociological Issues in Human Resource Management, 6(2), 74-79. https://doi.org/10.22381/pihrm6220187

Cho, K. R., Huang, C. H., \& Padmanabhan, P. (2014). Foreign ownership mode, executive compensation structure, and corporate governance: Has the literature missed an important link? Evidence from Taiwanese firms. International Business Review, 23(2), 371-380. https://doi.org/10.1016/j.ibusrev.2013.06.005

Ciftci, I., Tatoglu, E., Wood, G., Demirbag, M., \& Zaim, S. (2019). Corporate governance and firm performance in emerging markets: Evidence from Turkey. International Business Review, 28(1), 90-103.

https://doi.org/10.1016/j.ibusrev.2018.08.004

Combs, J. G., \& Skill, M. S. (2003). Managerialist and human capital explanations for key executive pay premiums: A contingency perspective. Academy of Management Journal, 46(1), 63-73. https://doi.org/10.5465/30040676

Conyon, M. J., \& Sadler, G. V. (2001). Executive pay, tournaments and corporate performance in UK firms. International Journal of Management Reviews, 3(2), 141-168. https://doi.org/10.1111/1468-2370.00060

Desender, K. A., Aguilera, R. V., Lópezpuertas-Lamy, M., \& Crespi, R. (2016). A clash of governance logics: Foreign ownership and board monitoring. Strategic Management Journal, 37(2), 349-369. https://doi.org/10.1002/smj.2344

Ellig, B. R. (2007). The complete guide to executive compensation. New York, NY: McGraw-Hill.

Epstein, M. J., \& Roy, M. J. (2005). Evaluating and monitoring CEO performance: evidence from US compensation committee reports. Corporate Governance: The international journal of business in society, 5(4), 75-87. https://doi.org/10.1108/14720700510616604

Eriksson, T. (2005). Managerial pay and executive turnover in Czech and Slovak republic. Economics of Transition, 13(4), 659-677. https://doi.org/10.1111/j.0967-0750.2005.00236.x

Farid, M., Conte, V., \& Lazarus, H. (2011). Toward a general model for executive compensation. Journal of Management Development, 30(1), 61-74. https://doi.org/10.1108/02621711111098370

Festing, M., \& Sahakiants, I. (2013). Path-dependent evolution of compensation systems in Central and Eastern Europe: A case study of multinational corporation subsidiaries in the Czech Republic, Poland and Hungary. European management journal, 31(4), 373-389. https://doi.org/10.1016/j.emj.2013.01.005

Fina (2018). Prosecna placa zaposenih kod poduzetnika. Retrived December 2018, from at https://www.fina.hr/novosti/lasset_publisher/pXc9EGB2gb7C/content/prosjecnaplaca-zaposlenih-kod-poduzetnika-5-372-kune-a-u-tripodrucja-djelatnosti-veca-od-7-500-ku-1 
Finkelstein, S., \& Boyd, B. K. (1998). How much does the CEO matter? The role of managerial discretion in the setting of CEO compensation. Academy of Management Journal, 41(2), 179-199. https://doi.org/10.5465/257101

Firth, M., Tam, M., \& Tang, M. (1999). The determinants of top management pay. Omega, 27(6), 617-635. https://doi.org/10.1016/S0305-0483(99)00021-3

Frydman, C., \& Saks, R. E. (2010). Executive compensation: A new view from a long-term perspective, 1936-2005. The Review of Financial Studies, 23(5), 2099-2138. https://doi.org/10.1093/rfs/hhp120

Gregory-Smith, I. (2012). Chief Executive Pay and Remuneration Committee Independence. Oxford Bulletin of Economics and Statistics, 74, 510-531. https://doi.org/10.1111/j.1468-0084.2011.00660.x

Johnston, J. (2005). Reward design and CEO succession in the UK. Applied Economics, 37(13), 1535-1541. https://doi.org/10.1080/00036840500193914

Jones, D. C., \& Mygind, N. (2011). Majority ownership and chief executive compensation. In Advances in the Economic Analysis of Participatory and Labor-Managed Firms (pp. 115-141). Emerald Group Publishing Limited. http://dx.doi.org/10.1108/S08853339(2011)0000012009

Kang, L. S., \& Nanda, P. (2017). How is managerial remuneration determined in India?. Journal of Accounting in Emerging Economies, 7(2), 154-172. https://doi.org/10.1108/JAEE-03-2015-0017

Kaplan, S. N. (2008). Are US CEOs Overpaid?. Academy of Management Perspectives, 22(2), 5-20. https://doi.org/10.5465/amp.2008.32739755

Kulich, C., Trojanowski, G., Ryan, M. K., Alexander Haslam, S., \& Renneboog, L. D. (2011). Who gets the carrot and who gets the stick? Evidence of gender disparities in executive remuneration. Strategic Management Journal, 32(3), 301-321. https://doi.org/10.1002/smi.878

Matolcsy, Z. P., \& Wright, A. P. (2006). Are we paying our CEOs too much?. JASSA, 4, 27-31.

McKnight, P., \& Tomkins, C. (2004). The implications of firm and individual characteristics on CEO pay. European Management Journal, 22(1), 27-40. https://doi.org/10.1016/j.emj.2003.11.013

Načinović, I. (2012). An exploration of executive compensation in Croatia-what are its implications within corporate governance?. In Proceedings of 1 st International Conference Corporate governance-new experiences: Implementation in South Eastern Europe, Zagreb.

Nica, E. (2018). Gig-based Working Arrangements: Business Patterns, Labor-Management Practices, and Regulations, Economics, Management, and Financial Markets, 13(1), 100-105. https://doi.org/10.22381/emfm13120185

Pepper, A., \& Gore, J. (2015). Behavioral agency theory: New foundations for theorizing about executive compensation. Journal of Management, 41(4), 10451068. https://doi.org/10.1177/0149206312461054
Pereira, I. N., \& Esperança, J. P. (2015). Top executive compensation in less developed capital markets. Corporate Governance, 15(1), 122-133. https://doi.org/10.1108/CG-11-2014-0128

Perry, T., \& Zenner, M. (2001). Pay for performance? Government regulation and the structure of compensation contracts. Journal of Financial Economics, 62(3), 453-488. https://doi.org/10.1016/S0304-405X(01)00083-6

Rahman, M., \& Mustafa, M. (2018). Determining total CEO compensation of selected US public companies. International Journal of Managerial Finance, 14(2), 170-187. https://doi.org/10.1108/lJMF-03-2017-0047

Rampling, P., Eddie, I., \& Liu, J. (2013). Executive remuneration in China: a literature review. Asian Review of Accounting, 21(2), 128-143. https://doi.org/10.1108/ARA-10-2012-0056

Sakawa, H., \& Watanabel, N. (2008). Relationship between managerial compensation and business performance in Japan: New evidence using micro data. Asian Economic Journal, 22(4), 431-455. https://doi.org/10.1111/j.1467-8381.2008.00285.x

Santalo, J. \& Kock, J. C. (2009). Division Director Versus CEO Compensation: New Insights Into the Determinants of Executive Pay. Journal of Management, 35 (4), 1047-1077. https://doi.org/10.1177/0149206308329965

Shinozaki, S., Moriyasu, H., \& Uchida, K. (2016). Shareholder composition and managerial compensation. Journal of Financial and Quantitative Analysis, 51(5), 1719-1738. https://doi.org/10.1017/S0022109016000636

Singh, P., \& Agarwal, N. C. (2003). Executive compensation: Examining an old issue from new perspectives. Compensation \& Benefits Review, 35(2), 48-54. https://doi.org/10.1177/0886368703251169

Tosi, H. L., Werner, S., Katz, J. P., \& Gomez-Mejia, L. R. (2000). How much does performance matter? A metaanalysis of CEO pay studies. Journal of Management, 26(2), 301-339. https://doi.org/10.1016/S0149-2063(99)00047-1

Vafeas, N. (2003). Further evidence on compensation committee composition as a determinant of CEO compensation. Financial Management, 32, 53-70. https://doi.org/10.2307/3666336

Victoravich, L. M., Xu, P., \& Gan, H. (2012). Institutional ownership and executive compensation: Evidence from US banks during the financial crisis. Managerial Finance, 39(1), 28-46. https://doi.org/10.1108/03074351311283559

World Economic Forum (2014), The Global Competitiveness Report 2014-2015, World Economic Forum, Geneva

Yoshikawa, T., Rasheed, A. A., \& Del Brio, E. B. (2010). The impact of firm strategy and foreign ownership on executive bonus compensation in Japanese firms. Journal of Business Research, 63(11), 12541260. https://doi.org/10.1016/j.jbusres.2010.06.012 
$\triangle$ Correspondence

Ivana Načinović Braje

Faculty of Economics and Business (FEB), University of Zagreb

Trg J.F. Kennedy 6, HR-10 000 Zagreb, Croatia

E-mail: ivana.nacinovic@efzg.hr 